\title{
Effects of forest certification towards sustainable community forestry in Nepal
}

\begin{abstract}
Pem N. Kandel ${ }^{1}$
In early 2005, 10,045 ha Community Forests (CFs) were certified in Bajhang and Dolakha districts of Nepal by using the Forest Stewardship Council (FSC) certification scheme. After two years of forest certification, subsequent questions are being asked such as: What benefits have certification brought for the Forest Users Groups (FUGs)? What tangible differences are there in forest management system because of forest certification? and What lessons have been learnt from the certified forests? In an attempt to answer these questions, a study was carried out in April 2007 in Dolakha district where 11 (2,182 ha) community managed forests were certified in 2005. On the basis of field study from two certified forests (Vitteripakha and Suspa) of the district, this paper analyzes the effects of forest certification and its implications for enhancing Sustainable Community Forestry (SCF) in Nepal.
\end{abstract}

Key words: Sustainable forest management, forest certification, community forestry

C ertification is one of the market based instruments that may contribute to improve management system of forests and support forestry sector development (FAO, 2000). Forest management certification is intended to improve forest management via market-based incentives (Bass, 2002). It is based on the assessment of the social, environmental and economical aspects of forest management as per the predetermined set of standard. Sustainable Forest Management (SFM) is the goal of any forest management to perpetuate social, ecological and economic functions of forest for ever. However, forest certification is a market driven approach to prove sustainability. Thus, before deciding about forest certification, market system should be analyzed to determine whether green consumers demand certified forest products or not.

Nepal does not export timber in international market but NTFPs are exported mainly to India. The Department of Forest (DoF) and FUGs collect US $\$ 15$ million yearly revenue from the trading of NTFPs (DoF, 2006).

Targeting NTFPs, 10,045 ha community managed forests were certified in February, 2005 in Nepal under Forest Stewardship Council (FSC) group certification scheme. Interim standards were developed within the framework of FSC standard for implementing the forest management activities and assessing the performance of forest management. Moreover, Nepal interim guidelines were formulated for managing NTFPs.

SmartWood ${ }^{2}$ made field assessment of the 11 community managed forests of Bajhang and Dolakha districts during September-October 2004 (Subedi, 2004). Based on the analysis and compilation of findings made by the SmartWood assessment team, 11 community forests were certified in February 2005. Forest certification was continued in community managed forests by following same processes. As a result, total number of certified community forests reached 21 and area increased to 14086 ha in 2006. The Federation of Community Forestry Users Nepal (FECOFUN) has received FSC/SmartWood Forest Management and Chain of Custody (FM/COC) certificates.

The USAID- Nepal programme has provided US\$ 5,00,000 fund for piloting FSC certification and Asia Network for Sustainable Agriculture and Bioresources (ANSAB) implemented the programme in the support of concerned stakeholders.

The objectives of certification were to verify sustainability of community-managed forests and piloting the approach to analyze how certification can be a vehicle to improve community forest management and enhance livelihoods of FUGs. This

\footnotetext{
${ }^{1}$ Research officer, Ministry of Forests and Soil Conservation (MFSC), Kathmandu, Nepal, Email: pemkandel@gmail.com

${ }^{2}$ Smartwood is one of the FSC accredited certified bodies based in United State of America (USA).
} 
study explores the effects of forest certification and analyses its merits and demerits in ecological, economic and social fronts.

\section{Material and Method}

\section{Study area}

\section{General about the district}

Covering an area of $2181 \mathrm{~km}^{2}$ area, Dolakha district is situated in the mid- north mountain of Nepal. Altitude of the district ranges from 732 meter to 7148 meter from the mean sea level. Forest land covers 47.4 percent of the total district's area whereas agriculture land comprises 26.5 percent.

Due to the latitudinal variation from south to north, district has got different forest types ranging from subtropical to alpine forests. The most important tree species found in the district are hill Sal forest (Shorea robusta) in lower altitude (600 -1000 meter), Khote Sallo (Pinus roxbrghaii), Utis (Alnus nepalensis), Rani Sallo(Pinus wallichiana), Gurans (Rhododendron arboretum) and Launth Salla (Taxus baccata) are the principal tree species found at higher altitude.

Lokta (Danphe bholua), Argeli (D. papyraceae,), Dhasingare (Gultheria farantissima), Girardiana diversiflora, Parmelia nepalensis, Angeri (Layania ovalifolia) etc. are the principal NTFPs found in the forest.

Community forestry is the key forest management strategy in the district. To date there are 289 CFs managing 30 percent of the total forest area in the district (DFO, 2007). Comprising an area of 14085 ha area, 21 CFs have been certified in Nepal during 2005 -2006. However, this study was conducted in the forests of Dolakha district certified only in 2005 to assess the effects of certification. The details of certified forests of Dolakha district are presented in Table 1.

Table 1: Detail CFs certified in Dolakha district in different years

\begin{tabular}{|c|c|c|c|}
\hline $\begin{array}{c}\text { Year of } \\
\text { Forest } \\
\text { certification }\end{array}$ & $\begin{array}{c}\text { Name of } \\
\text { Certified CFs }\end{array}$ & $\begin{array}{l}\text { Certified } \\
\text { forests } \\
\text { (ha) }\end{array}$ & $\begin{array}{c}\text { No. of } \\
\text { Household }\end{array}$ \\
\hline \multirow{6}{*}{2005} & Vitteripakha & 378 & 237 \\
\hline & Charnavati & 385 & 315 \\
\hline & Thulo Naagi & 239 & 250 \\
\hline & Kalobhir & 545 & 215 \\
\hline & Sushpa & 635 & 303 \\
\hline & Sub-total (5 CFs) & $2,182 \mathrm{~h}$ & \\
\hline \multirow{6}{*}{2006} & Bolte setidevi & 171 & 225 \\
\hline & Dhade Singhadevi & 340 & 311 \\
\hline & Jhareni & 208 & 186 \\
\hline & Balemdamji & 495 & 133 \\
\hline & Mjhkharka & 146 & 206 \\
\hline & Sub-total: 5 (CFs) & 1360 & \\
\hline Total & 10 & 3542 & \\
\hline
\end{tabular}

Source: DFO Dolakha District, April 2007

\section{Selection of certified forests}

Before approaching the actual field study, consultations and meetings were conducted with the personnel of Dolakha DFO and district level FCOFUN to formulate the criteria for selecting the certified CFs. Based on the consensus of the stakeholders, subsequent criteria were set up to select the certified forests for the field study (Table 2):

\section{Vitteripakha and Sushpa community forests}

Vitteripakha CF is situated in Boch Village Development Committee (VDC) Ward No 2 which is $7 \mathrm{~km}$ west from district headquarter Charikot.

Table 2: Criteria formulated to select certified CFs for the field study

\begin{tabular}{|c|c|c|}
\hline S.N. & $\begin{array}{l}\text { Criteria for selecting } \\
\text { certified forests }\end{array}$ & Justification \\
\hline 1 & $\begin{array}{l}\text { Forests certified in the } \\
\text { year } 2005 \text {. }\end{array}$ & $\begin{array}{l}\text { - To see the effects of forest certification; it needs certain time period. } \\
\text { - After two years of forest certification, changes can be looked at in forest } \\
\text { management system and socio- economic dimensions. }\end{array}$ \\
\hline 2 & $\begin{array}{l}\text { Certified FUGs having } \\
\text { mainly NTFPs-based } \\
\text { enterprises. }\end{array}$ & $\begin{array}{l}\text { - Forest certification is market driven approach, which assumes that buyers } \\
\text { will show a preference for certified product. } \\
\text { - It is important to evaluate the changes in production of forest-based raw } \\
\text { materials, processing and pricing system at local level before and after } \\
\text { certification. } \\
\text { - Thus, to know the value-chain system, a criterion was set to select certified } \\
\text { FUGs having NTFPs-based enterprises. }\end{array}$ \\
\hline 3 & $\begin{array}{l}\text { Selection of at least two } \\
\text { certified forests for } \\
\text { comparison and } \\
\text { validation of information. }\end{array}$ & $\begin{array}{l}\text { - At least two certified forests were suggested for the purpose of study so } \\
\text { that comparisons and validation can be made between. } \\
\text { - After knowing the limited time period (six days for whole study) and } \\
\text { resources, relatively accessible forests were recommended by the } \\
\text { stakeholders. }\end{array}$ \\
\hline
\end{tabular}


However, Sushpa CF lies in Chhemawoti VDC Ward No 9 and $10 \mathrm{Km}$ east- north from the district headquarter. These forests were certified in 2005 and both CFs have NTFPs based enterprises. Vitteripakha CF has Bhimeswore NTFP Production and Processing Private limited that produces handmade paper from Lokta (Danphe bholua) and Argeli ( $D$. Papyraceae). In Sushpa CF, there is Deudhunga Multipurpose Co-operative producing essential oil by using Dhasingare (Gultheria farantissima).

\section{Data collection method}

The main objective of the study was to assess the effects of forest certification in social, ecological and economic fronts. For the purpose, both secondary and primary data were collected from different sources and methods. The Operational Plans (OPs) of both CFs were reviewed to understand the structure and content of the plans.

A checklist was formulated to discuss with personnel of district level stakeholders, FUGs, NTFP collectors and NTFP entrepreneurs to borrow the data and information about changes brought in different dimensions due to forest certification. Plan formulation processes were discussed with the personnel of DFO, FECOFUN, ANSAB and FUGs members as well.

Including personnel of FECOFUN and DFO, a team was formed to visit the selected CFs, FUGs and enterprises. Following data collection instruments were executed to gather primary data.

1. Semi structured questionnaires were devised and executed to collect data from the local NTFPs collectors, traders and entrepreneurs.

2. A comprehensive checklist was developed for gathering information regarding benefits and tangible differences in forest management, livelihoods and forest conditions before and after forest certification. Data were collected from the FUGs, the local level forest officials and the district level FECOFUN.

3. Key informant interviews were carried out to understand the impact of forest certification at the institutional levels.

4. Focus group discussions were conducted so as to have in depth knowledge about particular theme or issue such as the impact on gender, indigenous people and adjacent communities to know the change owing to forest certification.

\section{Result and discussion}

The main aim of the study was to look at the effects of forest certification in sustainable community forestry in Nepal. The study was carried out in Vitteripakha and Sushpa CFs of Dolakha district. In general this study reveals that FSC certification has improved conservation status and enhanced system based management. Participation of FUGs has been substantially increased in planning and forest management processes.

Furthermore, members of FUGs have felt better ownership of their CFs than before certification. Forest certification has become a tool for institutional development of FUGs. But this study disclosed that there is lack of market network to sell the handmade paper and essential oil, which are being produced by using raw materials from certified and uncertified forests. As a management intervention forest certification has resulted positive change in forest management systems. However, no economic benefits have been brought to the FUGs and NTFPs based entrepreneurs due to forest certification. Overall findings of this study are presented under the successive sub-headings.

\section{Increasing community participation in planning}

Proper management planning is critical for SFM. Participation of stakeholders, sufficient and reliable scientific data are crucial for formulation of scientific and coherent forest management plan essential for SFM and certification. To be certified for sustainable production of timber and NTFPs, a management plan is even a prerequisite (FAO, 1998). Operational plans are basic instruments for managing timber, NTFPs and other purposes in community managed forests of Nepal.

Questions were asked to the district level stakeholders and members of FUGs regarding how they formulated their community forest OPs and what forest management standard did they use to depict on plan. According to the respondents, local standards were developed for sustainable community forestry with the involvement of key stakeholders at national and district levels by using the FSC Principles and Criteria (P\&C). Further, village and cluster meetings were organized to identify FUG level issues. A sample framework of standards adopted for sustainable community forestry is presenting in Figure 1. 
Figure 1: A sample framework of standards adopted for sustainable community forestry in certified CFs

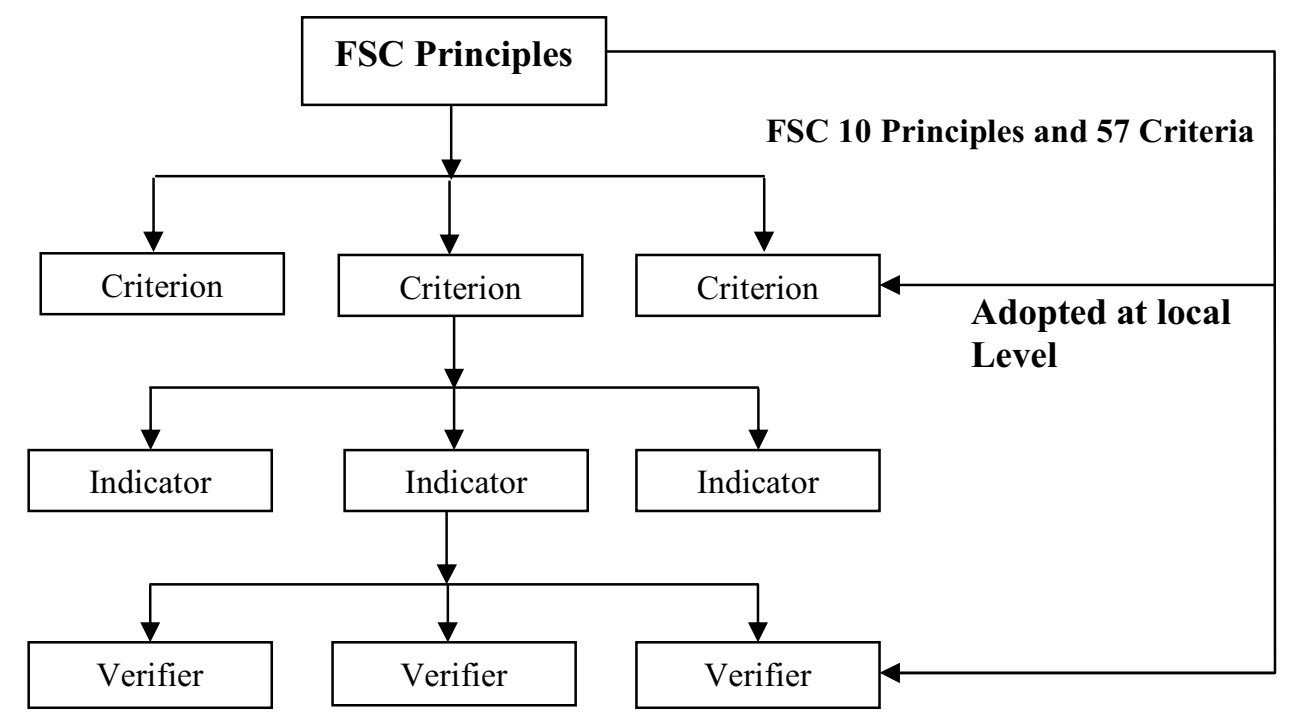

This study reveals that planning process is more participatory and rational in both certified forests than before. Resource inventory including NTFPs was carried out in the community managed forests and social data were adequately gathered by using different data collection tools. As a result, OPs have become more scientific to balance social, ecological and economic facets of forest. Annual allowable harvest of timber and NTFPs has been calculated on the basis of Growing Stock (GS) and estimated Mean Annual Increment (MAI). Table 3 presents the annual allowable harvest of timber and NTFPs in the two CFs.

Furthermore, participation of women, ethnic and of deprived communities is significantly increased in forest management as result of increase in awareness and formation of sub group within the FUGs.

\section{Improving forest conservation and management}

Before forest certification, timber and NTFPs harvesting system was unsustainable. The executive committee of FUGs used to issue permit to users and contractors for felling trees while the $\mathrm{DOF}$ issued collection permit for NTFPs as the provision of NTFPs management was not included in the OPs. Monitoring system was poor in community forest.
In many cases users members and contactors harvested two to three times more quantity of timber and NTFPs. As a result, forest resources were overexploited.

After forest certification, executive committee firstly collects the information on demand of timber for FUGs and then harvests the quantity without exceeding the annual allowable cut. Both Vitteripakha and Suspa CFs have their own timber depots.

They collect timber in depots and distribute according to demand at reasonable price. Now, the management of NTFPs are under the full control of CFUGs. These initiatives have positive contribution to enhance the sustainability of community managed forests.

\section{Effect on Ecological dimensions}

Community awareness is increasing to conserve water source, bio-diversity and soil. In addition, seed trees are left to ensure natural regeneration. Free grazing is discouraged inside the community forests. Poaching of wild animals has been totally banned. These strategies will have long term favorable impacts on sustainable community forestry in Nepal.

Table 3: Annual allowable harvest of timber and NTFPs in two CFs

\begin{tabular}{|c|c|c|c|c|c|}
\hline Name of CFs & Timber (cft) & & NT & & \\
\hline \multirow{2}{*}{ Vitteripakha } & \multirow{2}{*}{5835} & 1 & 2 & 3 & 4 \\
\hline & & $360-2266$ & $295-441$ & 200 & 3965 \\
\hline Sushpa & 4679 & $847-9747$ & $628-764$ & 150 & 1133 \\
\hline
\end{tabular}

Source: Respective operational plans (2005). 


\section{Effect on institutional and social extents}

Varieties of training were conducted in the FUGs to adopt SFM and certification system. As a result, institutional capabilities of certified FUGs have greatly increased. Record system in certified FUGs is far better than in uncertified ones. Transparency is improving and FUGs are becoming able for annual planning with projecting source of income and items of expenditure.

Sub-groups comprising women, poor, ethnic and untouchable castes have been formed within FUGs in surveyed areas. Sub-groups found to be contributing to enhance the social cohesion and increase the ownership towards their $\mathrm{CF}$, which has positive implications in sustainable forestry. It is claimed that communities, indigenous peoples, local communities and workers look to certification as a way to improve their social situation (FSC,2003). In the study areas, indigenous and traditional rights of yak herders have been secured. Certain forest areas within the CFs have been allocated for cattle grazing. There is a provision to allocate certain amount of FUG fund to cure victims, if FUG members and other forest workers become injured in the forests. This reveals that awareness on social security has greatly increased.

\section{Effects on economic aspects}

The aim of management certification is intended to improve forest management via market-based incentives (FSC, 2007). However, chain of custody certification has not been performed yet to export the NTFPs from certified forests of Nepal to increase the market share in national and international markets. Although benefit- cost analysis was beyond the scope of this study, financial investment was determined to know the cost of certification.

ANSAB invested US $\$ 5,00,000$ to build the national capacity on forest certification and certify 14,086 ha community-managed forest in two districts. The cost of forest certification was US\$35.5 per hectare. This study unveils that no significant and tangible economic benefits have been gained so far by the NTFPs collectors, entrepreneurs, ultra poor and others after certification.

Although there were no significant visible differences in economic aspects, some structural and institutional reforms have been made in enterprise development,
FUG fund mobilization and sub-group formation. Before certification, stipulated enterprises were in the hands of individual entrepreneur. However, now those have been shifted to cooperative. The FUGs and their members have become shareholders of enterprises which are being collectively managed. According to the shareholders, both the enterprises were below the breakeven point at this stage due to lack of market to sell their products. But new system will have multiplier impacts in the long run for sustainable use of raw materials and income generation as well.

Ultra-poor households have been identified and the DFO have started to lease forestland to them so that they can generate income through the support of DFO, ANSAB and other concerning programme. At national level, about 3 percent FUG fund is allocated for pro-poor activities. However, in Vitteri and Suspa CFs more that 20 percent fund has been allocated to support pro-poor activities which is perhaps an example of significant change in economic dimension realized after certification.

\section{Lesson learnt and direction for future}

As an instrument, certification has both strengths and weaknesses (FAO, 2001, 2007). However, it varies according to the specific circumstances of the country, the ownership of the forests, the socioeconomic environment and most importantly the market system. This study from the two certified CFs of Nepal discloses that degree of community participation, transparency and downward accountability have been increased in forest management system. However, some important questions regarding forest certification that have yet to be adequately addressed include: (i) which must be in priority whether sustainable forest management or forest certification? (ii) where is the market for certified products? and (iii) how certification can be a vehicle for poverty alleviation? Subsequent lessons have been learnt from this study which are crucial to handle forest certification issue in Nepal.

Sustainable forest management is an important goal of any forestry model e.g. Community forestry of Nepal. However, forest certification is a tool to verify management standard. In addition, certification is an important innovation in the market of forestry. Thus, certification is a market-driven approach. A point that should be noted is that SFM is possible without certification, but certification is not possible without 
SFM. SFM is the foundation of forestry but certification is used when markets demand certified products and certification provides incentives to forest managers and owners. Hence, it is high time now to formulate our own forest management standard to apply in our forestry.

Certification process increases the cost (both financial and managerial). Market analysis is prerequisite to know whether certified products are demanded at national and/or international markets. Our main NTFP market is India and this country has no interest in certified products. If we want to export them beyond India, quantity and quality of certified forest products will be crucial. However before applying certification system in community forestry, new markets must be sought first.

Nepal is a country with high rate of poverty, which is the most serious challenge in achieving sustainable forest management. The nation is shifting its strategies to address more effectively the need for the forestry sector to contribute to poverty reduction. As a management intervention, certification should contribute to reduce the poverty.

Eventually, cost effectiveness is key to apply certification. Certification cost in Nepal shows US\$ 35.5 per ha, which is higher compared to other countries. To reduce the cost, national capability must be developed towards sustainable forest management and certification.

\section{Conclusion}

This study concludes that certification has brought tangible differences in forest management system. However, no positive chages have been found so far in employment and income generation for FUGs after certification. As a result, certification has not shown any positive effect in rural livelihood yet. Thus, initiation of SFM is the first step demanding for sustainable community forestry in Nepal. Certification comes later, when Nepal will export substantial quantity of forest products from community managed forests and market mechanism will demand certified products at higher price.

\section{Acknowledgements}

I am grateful to Hideo Sakai, Professor of Tokyo University Japan for providing me invaluable guidance and encouragement to carry out this study. I would like to thank personnel of Dolakha DFO and FECOFUN for their generous support during field study. I am indebted to people of Vetteripakha and Suspa CFs for their cooperation during field work. Eventually, my thanks go to Mr. S.M Shrestha for his valuable suggestions to refine the article.

\section{References}

DFO. 2007. Community database. District Forest Office (DFO), Dolakha Charikote, Nepal.

FAO. 2000. Certification and forest product labelling: A review. FAO- Asia- Pacific Forestry Commission, eighteen sessions. Secretariat note Noosaville, Queensland, Australia, 15-19 May 2000.

FAO. 2007. State of the World's Forests 2007. Food and Agriculture Organizations, Rome 2007.

Subedi, B. P. 2004. FSC Certification Progress in Nepal, a synopsis. Asia Network for Sustainable Agriculture and Bio-resources (ANSAB). www.ansab.org

Bass, S. 2002. "The sustainable forestry hand book, Earthscan publications Ltd London."

DoF. 2006. Revenue record of Forests products from Department of Forest (DoF), Kathmandu Nepal.

FAO. 2001. State of the World's Forests. Rome, Food and Agriculture Organization of the United Nations: 181.

FSC. 2003. FSC websites links http:/www.fsc.org, Forest Stewardship Council (FSC). 2003.

FSC. 2007.www.fsc.org, A case study from FSC certified forest, Forest Stewardship Council. 